\title{
Estimates of genetic components and regression analysis for grain yield and various morphological traits in bread wheat (Triticum aestivum L.)
}

\author{
Sandeep Kumar ${ }^{1}$, Pradeep Kumar ${ }^{2 *}$, Vichitra Kumar Arya ${ }^{2}$, Ravi Kumar ${ }^{1}$ and \\ S. A. Kerkhi ${ }^{1}$ \\ ${ }^{1}$ Sardar Vallabhbhai Patel University of Agriculture and Technology, Meerut - 250110 (UP), INDIA \\ ${ }^{2}$ Indian Institute of Wheat and Barley Research, Karnal-132001 (Haryana), INDIA \\ *Corresponding author. E-mail : pradeeptaliyan231@gmail.com
}

Received: October 5, 2016; Revised received: May 30, 2017; Accepted: January 2, 2018

\begin{abstract}
The present study was conducted to estimate the gentic components and regression analysis for grain yield and various morphological traits in bread wheat involving 10 parents and their $45 \mathrm{~F}_{1} \mathrm{~s}$ (half diallel) during 201213 and 2013-14. Significant additive (D) and dominance $\left(H_{1}\right)$ variance for the traits indicated that expression of these traits is control by both additive and dominance gene action. Average degree of dominance $\left(H_{1} / D\right)^{1 / 2}$ were more than unity for the traits (peduncle length, flag leaf area, productive tillers, biological yield, grain yield, harvest index) indicating the preponderance of over dominance gene action. The estimates of $h^{2}$ were positive and significant for days to ear emergence, peduncle length, productive tillers, biological yield and grain yield indicated dominance of genetic components in $F_{1}$ s. Positive and significant values of $F$ were estimated for days to ear emergence, days to $50 \%$ flowering, spike length, flag leaf area and grain yield in $F_{1} s$ indicating the preponderance of dominance and positive genes in the parents involved. The theoretical value $(0.25)$ of $\left(\mathrm{H}_{2} / 4 \mathrm{H}_{1}\right)$ for all the traits indicated asymmetrical distribution of positive and negative genes. The proportion of dominant and recessive alleles indicated presence of dominant alleles in the parents. The traits showing more than $30 \%$ narrow sanse heritability could be rewarding for further improvement in grain yield in bread wheat. Regression analysis indicated that the traits (days to ear emergence, days to $50 \%$ flowering, peduncle length, flag leaf area, productive tillers, harvest index, biological yield and grain yield) control by over dominance type of gene action. The parent RAJ 4246 contained maximum dominant genes for days to ear emergence and days to 50\% flowering; HD 2733 for spike length and flag leaf area and HD 2824 for productive tillers, biological yield and grain yield used as donors in multiple traits breeding programme to develop high yielding wheat genotypes.
\end{abstract}

Keywords: Bread wheat, Diallel analysis, Genetic components, Grain yield, Regression analysis

\section{INTRODUCTION}

Wheat (Triticum aestivum L.) is most important food crop over the entire world including India. In India, wheat is the second most important food crop after rice both in terms of area and production planted to an area of 30.23 million hectares with production amounting to 93.50 million tons (Anonymous 2016). Genetic analysis of wheat has shown that grain yield a highly complex trait is determined by component traits and these component traits affect the yield directly or indirectly. Therefore, knowledge about the nature and magnitude of gene effects of yield traits and their expression are of paramount importance in formulating an efficient breeding programme. Various biometrical tools help plant breeders in ascertaining the information on various genetic aspects for a successful breeding programme. Diallel cross technique developed and illustrated by Hayman (1954) to provides information in early generations on genetic mechanism involved in character expression from all possible single crosses. Improvement in the wheat yield is possible by knowing the gene action of the parents with wider adaptability. The results obtained from diallel analysis of genetic components throw light on the presence or absence and magnitude of additive and non-additive gene action and estimates of gene action are important in launching a successful wheat breeding programme. Therefore, the objective of the present study was to estimates the genetic components and regression analysis, identify the parents with most valuable gene and contribution of various morphological traits to grain yield in bread wheat .

\section{MATERIALS AND METHODS}

The base material consists 10 diverse genotypes of bread wheat (Triticum aestivum L.) namely, PBW 435, HD 2967, MP 3336, MP 4010, DBW 90, HD 2824, HD 3095, RAJ 4246, NW 5038 and HD 2733 was 
planted at Crop Research Centre, Sardar Vallabhbhai Patel University of Agriculture and Technology, Meerut during rabi 2012-2013 for attempting crossing in a $10 \times 10$ diallel fasion excluding reciprocals. In the next crop season (i.e. rabi 2013-2014), experimental material consisted total 55 genotypes (10 parents and their $\left.45 \mathrm{~F}_{1} \mathrm{~s}\right)$ was sown in a randomized block design with three replications. Seeds of each of the parental lines and also $F_{1} s$ were dibbled in two row plot of 2 meter length maintaining spacing of $10 \mathrm{~cm}$ among plants within a row and $23 \mathrm{~cm}$ between rows. All the standard agronomical practices were followed to raise normal crop. Observations were recorded on five randomly selected plants in each replication for nine morphological traits namely; days to ear emergence, days to $50 \%$ flowering, flag leaf area $\left(\mathrm{cm}^{2}\right)$, spike length $(\mathrm{cm})$, peduncle length $(\mathrm{cm})$, number of productive tillers per plant, harvest index (\%), biological yield per plant (g) and grain yield per plant (g). Diallel analysis was carried out by method described by Mather and Jinks (1982) and genetic parameters by method described by Hayman (1954). The analysis of variance was estimated following the method of Panse and Sukhamte, (1967). The expectations in biometrical scale for various statistics were worked out following Hayman, (1954) approach. Where, $\mathrm{D}=$ variation due to genetic effects, $\mathrm{H}_{1}=$ variation due to dominance genetic effects, $\mathrm{H}_{2}=$ proportion of $+/$-genes, $\mathrm{F}=$ mean covariance of additive and dominance effects, $\mathrm{h}^{2}=$ overall dominance effects and $\mathrm{E}=$ variation attributed to environmental effects. Related statistics of components of variance included (i) average degree of dominance $\left(\mathrm{H}_{1} / \mathrm{D}\right)^{1 / 2}$, (ii) proportion of genes with positive and negative effects in the parents $\left(\mathrm{H}_{2} / 4 \hat{\mathrm{H}}_{1}\right)$, (iii) proportion of dominant and recessive genes in the parents, $\mathrm{F}$ being in-significantly different from zero [(4D H $)^{0.5}$ $\left.+\mathrm{F} /\left(4 \mathrm{D} \mathrm{H} \mathrm{H}_{1}\right)^{1 / 2}-\mathrm{F}\right]$ and (iv) number of groups of genes control the traits and exhibited dominance $\left(\mathrm{h}_{2} / \mathrm{H}_{2}\right)$ to work out gene action for various traits under study. Graphical analysis (Wr-Vr) was done according to the method suggested by Hayman, (1954). Information about gene action was given by plotting the covariance of each array against its variance. The slope and position of the regression line fitted to the array points within the limiting parabola indicated the degree of dominance and the presence or absence of gene interaction. The position of regression line on $\mathrm{Wr}-\mathrm{Vr}$ graph provides information about the average degree of dominance given below: (1) When the regression line passes through the origin, it indicates dominance $\left(\mathrm{D}=\mathrm{H}_{1}\right)$, (2) When it passes above the origin and cut the Wraxis, it shows partial dominance $\left(\mathrm{D}>\mathrm{H}_{1}\right),(3)$ When it passes above the origin, cutting $\mathrm{Wr}$-axis and touching the limiting parabola, it suggests the no dominance and (4) when it passes below the origin, cut the Vr-axis, it indicates over dominance.

\section{RESULTS AND DISCUSSION}

The estimated value of all the genetic components of variance $\left(\mathrm{D}, \mathrm{H}_{1}, \mathrm{H}_{2}, \mathrm{~h}^{2}, \mathrm{~F}\right.$ and $\left.\mathrm{E}\right)$ alongwith standard error and related parameters in wheat crop are presented in (Table 3). The additive genetic variance were significant (at $<5 \%$ level of significance) for seven traits (days to ear emergence, days to $50 \%$ flowering, peduncle length, flag leaf area, spike length, biological yield, grain yield ) indicating the predominance of additive gene action in the inheritance of these traits. Whereas, dominance component was significant for all the traits (days to ear emergence, days to $50 \%$ flowering, peduncle length, flag leaf area, productive tillers , spike length, biological yield, grain yield and harvest index) in $F_{1}$ generation. This showed higher magnitude of dominance components for all the traits under study. The estimates of $\mathrm{H}_{1}$ were higher than the estimates of $\mathrm{H}_{2}$ for all the traits under study indicating the unequal allelic frequencies at relevant loci in the populations. These results indicated that both additive and dominance gene action played important role in the inheritance of these traits. Similar findings of additive and dominant effects were also reported by Dayal et al. (2003), Singh et al. (2003), Singh et al,(2008), Singh et al. (2012), Singh et al. (2014), Kumar et al. (2015) and Kumar et al. (2016a) for different yield component in wheat. The analysis of variance components indicated that both additive and dominance variance are significant for almost all the trait under study, indicating that the expression of all these traits is controlled by both additive and dominance (non-additive) gene action. However, dominance components were predominent for all the traits under study. Similar findings

Table 1. Pedigree and origin of the parental lines are given in the following table.

\begin{tabular}{lllll}
\hline Parents & Parentage/ pedigree & Area of adoption & Production condition & Origin \\
\hline PBW435 & HD 2160/CALIDAD & & & Ludhiana \\
HD 2967 & ALD/COC//URES/HD2160M/HD2278 & NWPZ/NEPZ & TS, IR & New Delhi \\
MP 3336 & HD2402/4W173 & CZ & LS, IR & Jabalpur \\
MP 4010 & ANGOSTURA88 & $\mathrm{CZ}$ & LS, IR & Jabalpur \\
DBW 90 & HUW468/WH 730 & NWPZ & LS, IR & Karnal \\
HD 2824 & PTO-1/CNO79/PRL/GAA/3/HD 1951 & NEPZ & TS, IR & New Delhi \\
HD 3095 & CPAN300/WR426//HW2007//HD2851 & & & New Delhi \\
RAJ 4246 & RAJ 3765/WR544 & & & Durgapura \\
NW 5038 & WAXWING*2/VIVITSI & & Kumarganj \\
HD 2733 & ATTILA/3/TUI/CARC//CHENICHTO/4/ATTILA & NWPZ/NEPZ & LS/VLS, IR & New Delhi \\
\hline
\end{tabular}




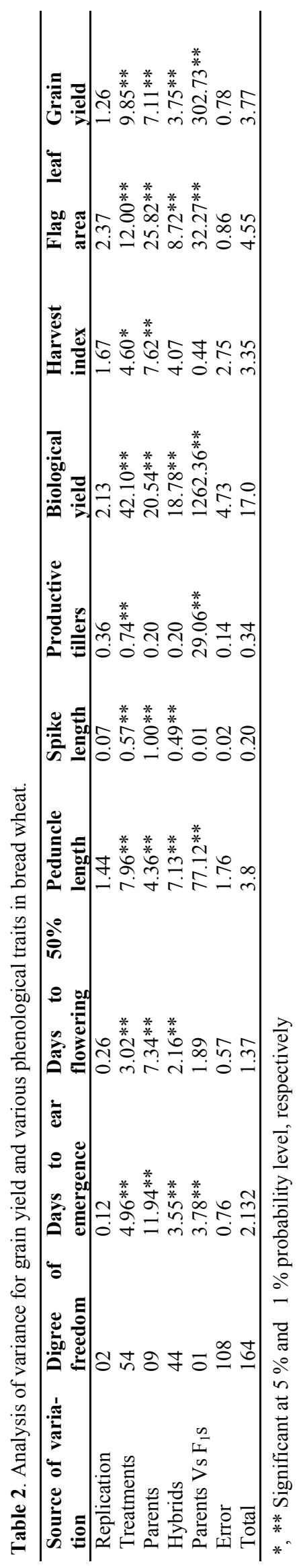

were also reported by Singh et al. (2012), Singh et al. (2014), Kumar et al. (2015) and Kumar et al. (2016a) in wheat crop. Positive and significant value of Fcomponent of genetic variance for the traits namely days to ear emergence, days to $50 \%$ flowering, spike length, flag leaf area and grain yield in $F_{1}$ cross combinations indicated possible role of dominant and positive alleles in the parents for improving these traits. Similar finding were also reported by Singh et al. (2003), Dere and Yildrin (2006), Singh et al.(2008), Kumar et al. (2015) and Kumar et al. (2016a) in wheat crop at different locations of India. The estimates of $\mathrm{h}^{2}$ were positive and significant for days to ear emergence, peduncle length, productive tillers, biological yield, grain yield indicated dominance of genetic components in $F_{1} s$. Whereas, non-significant values were observed for remaining traits that indicated partial dominance of genetic components. Kumar et al. (2015) and Kumar et al. (2016a) also reported similar findings in wheat. The environmental component (E) were significant for six traits and non-significant for other three traits. However, its value was much lower than that of $\mathrm{D}$ or $\mathrm{H}_{1}$ components for all traits. The traits showing significant environmental components included days to ear emergence, days to $50 \%$ flowering, peduncle length, productive tillers, biological yield and harvest index. It may be concluded from the above results that these traits are highly influenced by environmental effects. Singh et al. (2003), Singh et al. (2014) and Kumar et al. (2016a) also reported that non additive type of gene effects are important for number of productive tillers per plant.

The estimates of average degree of dominance expressed as $\left(\mathrm{H}_{1} / \mathrm{D}\right)^{1 / 2}$ were found to be more than unity in $\mathrm{F}_{1 \mathrm{~s}}$ cross combinations for the traits namely, peduncle length, flag leaf area, productive tillers , biological yield, grain yield and harvest index indicating the preponderance of over dominance type of gene action. Whereas, the average degree of dominance for days to ear emergence, days to $50 \%$ flowering and spike length was found less than unity and greater than zero indicated partial dominance. Similar findings for dominance and partial dominance for different yield related traits in wheat were reported by Singh et al. (2003), Dere and Yildrin (2006), Kumar et al.(2015) and Kumar et al. (2016a). The proportion of genes with positive and negative effects in the parents $\left(\mathrm{H}_{2} / 4 \mathrm{H}_{1}\right)$ was found less than its theoretical value $(0.25)$ for all thenine traits in $F_{1}$ combinations indicated asymmetrical distribution of positive and negative genes in the parents. Similar finding were also reported by Dayal et al. (2003), Singh et al.(2003), Kumar et al. (2015) and Kumar et al. (2016a) in wheat crop.

The estimates of the ratio showing proportion of dominant and recessive alleles among the parents was more than unity for eight traits (days to ear emergence, days to $50 \%$ flowering, productive tillers, spike length, 
Sandeep Kumar et al. / J. Appl. \& Nat. Sci. 10 (1): 6 - 11 (2018)

Table 3. Genetic components and related parameters for grain yield and various morphological traits in bread wheat.

\begin{tabular}{llllllllll}
\hline $\begin{array}{l}\text { Genetic } \\
\text { Parameters }\end{array}$ & $\begin{array}{l}\text { Days to ear } \\
\text { emergence }\end{array}$ & $\begin{array}{l}\text { Days to 50 } \\
\text { \% flowering }\end{array}$ & $\begin{array}{l}\text { Peduncle } \\
\text { length }\end{array}$ & $\begin{array}{l}\text { Spike } \\
\text { length }\end{array}$ & $\begin{array}{l}\text { Produc- } \\
\text { tive tillers }\end{array}$ & $\begin{array}{l}\text { Biologi- } \\
\text { cal yield }\end{array}$ & $\begin{array}{l}\text { Harvest } \\
\text { index }\end{array}$ & $\begin{array}{l}\text { Flag leaf } \\
\text { area }\end{array}$ & $\begin{array}{l}\text { Grain } \\
\text { yield }\end{array}$ \\
\hline $\mathrm{D}$ & $3.732^{*}$ & $2.258^{*}$ & $0.868^{*}$ & $0.326^{*}$ & 0.018 & $5.287^{*}$ & 1.632 & $8.312^{*}$ & $2.106^{*}$ \\
$\mathrm{SE}$ & 0.103 & 0.104 & 0.430 & 0.026 & 0.018 & 2.150 & 1.186 & 1.910 & 0.526 \\
$\mathrm{H}_{1}$ & $0.785^{*}$ & $0.835^{*}$ & $4.795^{*}$ & $0.312^{*}$ & $0.690^{*}$ & $42.997^{*}$ & $5.919^{*}$ & $17.826^{*}$ & $10.369^{*}$ \\
$\mathrm{SE}$ & 0.218 & 0.222 & 0.915 & 0.055 & 0.091 & 4.576 & 2.524 & 4.066 & 1.119 \\
$\mathrm{H}_{2}$ & $0.698^{*}$ & $0.657^{*}$ & $4.062^{*}$ & $0.197^{*}$ & $0.630^{*}$ & $34.365^{*}$ & 3.793 & $12.069^{*}$ & $8.284^{*}$ \\
$\mathrm{SE}$ & 0.186 & 0.189 & 0.778 & 0.046 & 0.077 & 3.889 & 2.145 & 3.455 & 0.951 \\
$\mathrm{~F}$ & $1.323^{*}$ & $1.077^{*}$ & -1.229 & $0.160^{*}$ & 0.067 & 9.078 & 3.580 & $12.791^{*}$ & $3.265^{*}$ \\
$\mathrm{SE}$ & 0.237 & 0.241 & 0.992 & 0.059 & 0.098 & 4.960 & 2.736 & 4.407 & 1.213 \\
$\mathrm{~h}^{2}$ & $0.410^{*}$ & 0.182 & $9.969^{*}$ & -0.002 & $3.819^{*}$ & $166.07^{*}$ & -0.269 & 4.154 & $39.866^{*}$ \\
$\mathrm{SE}$ & 0.124 & 0.126 & 0.521 & 0.031 & 0.052 & 2.603 & 1.436 & 2.313 & 0.636 \\
$\mathrm{E}$ & $0.248^{*}$ & $0.188^{*}$ & $0.586^{*}$ & 0.008 & $0.047 *$ & $1.561 *$ & $0.910^{*}$ & 0.294 & 0.263 \\
$\mathrm{SE}$ & 0.031 & 0.031 & 0.130 & 0.008 & 0.013 & 0.648 & 0.358 & 0.576 & 0.158 \\
$\left(\mathrm{H}_{1} / \mathrm{D}\right)^{1 / 2}$ & 0.459 & 0.608 & 2.351 & 0.978 & 6.109 & 2.852 & 1.905 & 1.464 & 2.219 \\
$\mathrm{H}_{2} / 4 \mathrm{H}_{1}$ & 0.222 & 0.197 & 0.212 & 0.158 & 0.228 & 0.200 & 0.160 & 0.169 & 0.200 \\
$\left.(4 \mathrm{DH})_{1}\right)^{1 / 2}+\mathrm{F} /$ & 2.260 & 2.291 & 0.537 & 1.673 & 1.842 & 1.861 & 3.718 & 3.214 & 2.074 \\
$\left.(4 \mathrm{DH})_{1}\right)^{1 / 2}-\mathrm{F}$ & & & & & & & & & \\
$\mathrm{h}^{2} / \mathrm{H}_{2}$ & 0.587 & 0.278 & 2.454 & -0.009 & 6.064 & 4.833 & -0.071 & 0.344 & 4.813 \\
$\mathrm{r}$ & 0.987 & 0.939 & 0.672 & 0.817 & 0.793 & 0.841 & 0.040 & 0.426 & 0.809 \\
$\mathrm{~h}^{2} \mathrm{~ns}^{*}$ & 75.00 & 11.00 & 69.00 & 36.00 & 47.00 & 30.00 & 42.00 & 91.00 & 71.00 \\
\hline
\end{tabular}

*, ** Significant at $5 \%$ and $1 \%$ probability level, respectively

biological yield, flag leaf area, grain yield and harvest index) indicated role of more dominant alleles in the parents for these traits. Whereas, this ratio was less than unity forpeduncle length reflecting the role of more recessive alleles in the parents for these traits and similar findings were reported by Kumar et al. (2015) and Kumar et al. (2016a) in wheat.

The estimates of ratio for number of gene groups was more than unity for four traits (peduncle length, productive tillers, biological yield, grain yield) indicated involvement of more than one major gene groups that are responsible for inheritance of these traits. Whereas, this ratio was less than unity for the traits (days to ear emergence, days to $50 \%$ flowering, flag leaf area, and harvest index) indicated the involvement of single gene groups in the inheritance of these traits. Similar findings were also reported by Singh et al. (2003) and Kumar et al. (2015) in wheat crop.The traits which showed dominance or non-additive type of gene effects, might be improved by intermating the most desirable segregates followed by selection. Whereas, traits that exhibited predominance of non-additive gene effects would require maintaining considerable heterozygosity through mating of selected plant in early segerigating generations to attain maximum genetic gain. Therefore, few cycles of recurrent selection followed by pedigree breeding would be effective for the improvement of grain yield.

The narrow-sense heritability (Table 3) was high for flag leaf area (91), days to ear emergence (75), grain yield (71), peduncle length (69), productive tillers (47), harvest index (42), spike length (36) and biological yield (30). Therefore, early generation selection for these traits will be rewarding. Kumar et al. (2016a) reported moderate estimates of narrow sense heritabil- ity for productive tillers and spike length whereas Singh et al. (2014) reported high estimates of narrow sense heritability for spike length in wheat crop.

The graphical representation of $\mathrm{Wr}-\mathrm{Vr}$ graph (Fig. 1) indicated the over dominance type of gene action, as the regression line cuts $\mathrm{Wr}$-axis just below the origin for days to ear emergence, days to $50 \%$ flowering, peduncle length, flag leaf area, productive tillers, harvest index, biological yield and grain yield whereas positive intercepts of $\mathrm{Wr}-\mathrm{Vr}$ regression line supported complete dominance type of gene action for spike length. Similar findings for different yield related traits were also reported by Kumar et al. (2016b) and Kumar et al. (2016c).

It is indicated from the graphic illustration (Fig. 1) that parent, being closest to the origin possessed maximum dominant genes therefore RAJ 4246 contain maximum dominant genes for days to ear emergence and days to 50\% flowering; HD 2733 for spike length and flag leaf area, PBW 435 for peduncle length; HD 2824 for productive tillers, biological yield and grain yield and HD 2967 for harvest index. Similar findings were also reported by Kumar et al. (2016b) and Kumar et al. (2016c) for different morphological traits in wheat crop. Graphic illustration indicated that the parent being farthest from the origin contained maximum recessive genes therefore, HD 2967 contain maximum recessive genes for days to ear emergence and days to 50\% flowering; MP 4010 for spike lenght; HD 3095 for peduncle length; RAJ 4246 for productive tillers and harvest index; PBW 435 for biological yield and HD 2824. Similar findings were also reported by $\mathrm{Ku}-$ mar et al. (2016b) and Kumar et al. (2016c) in wheat. Since the parental lines used are mostly recently released varieties, this set could serve as base material 
Sandeep Kumar et al. / J. Appl. \& Nat. Sci. 10 (1): 6 - 11 (2018)

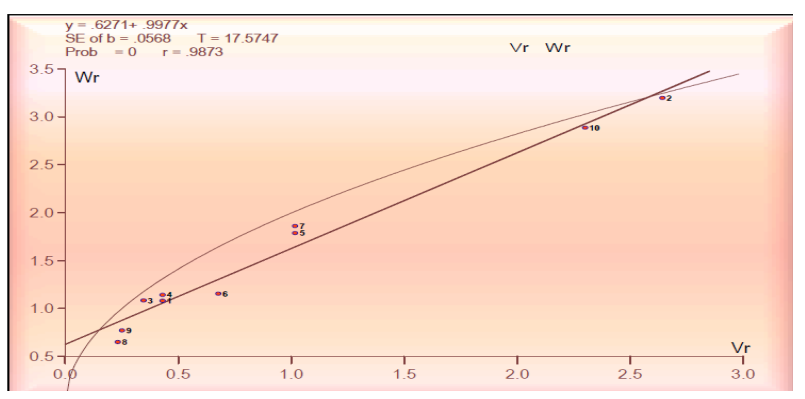

(a)

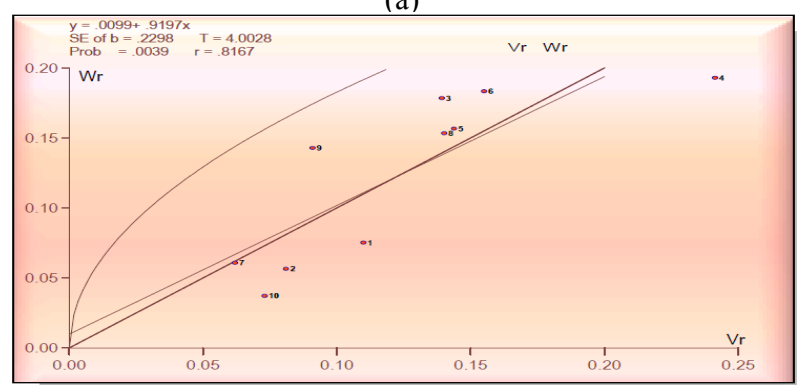

(c)

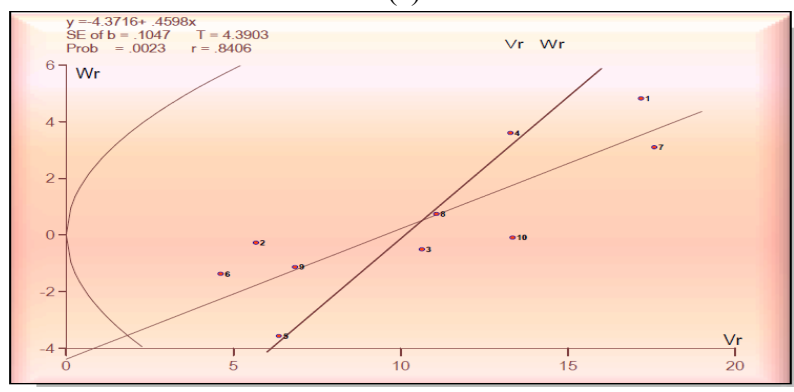

(e)

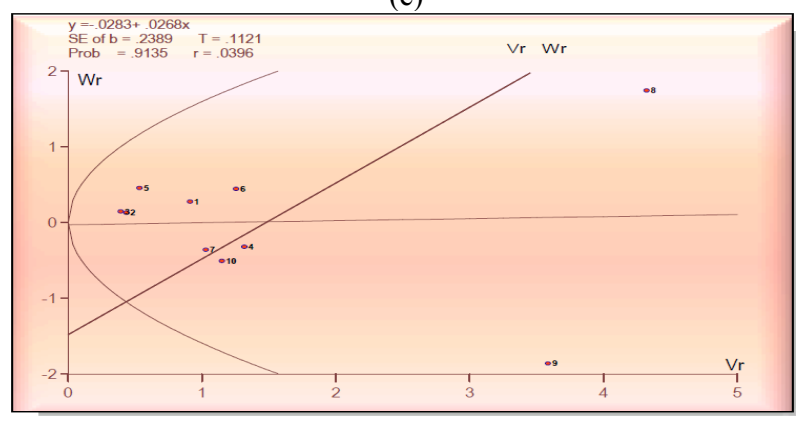

(g)

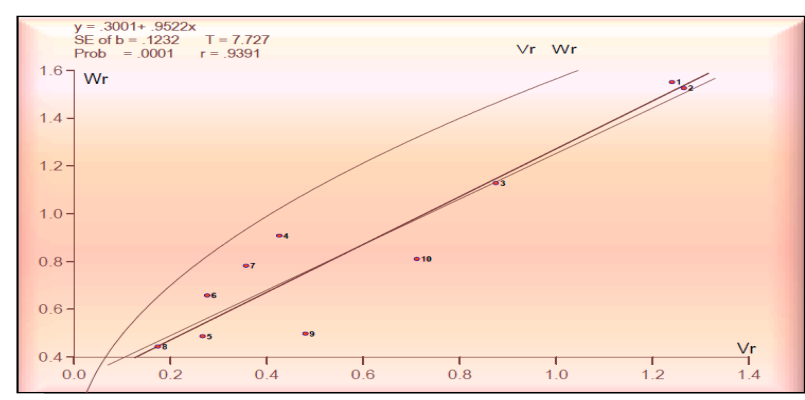

(b)

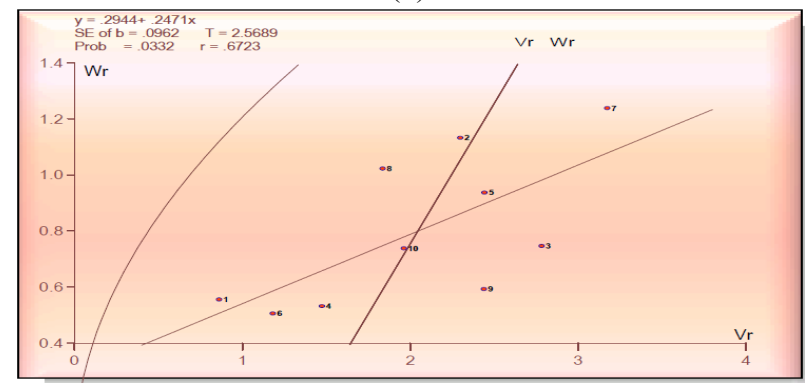

(d)

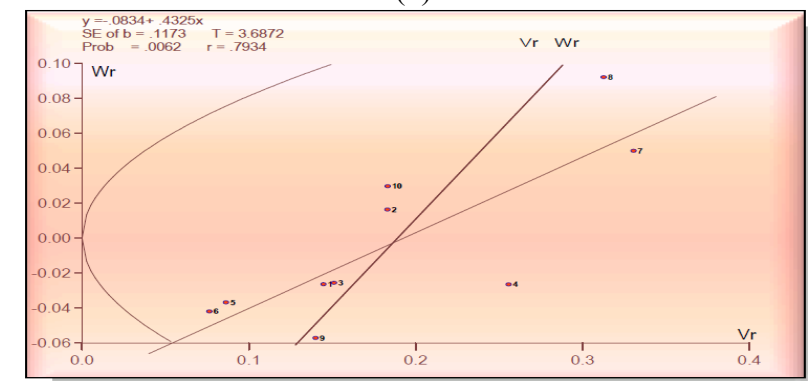

(f)

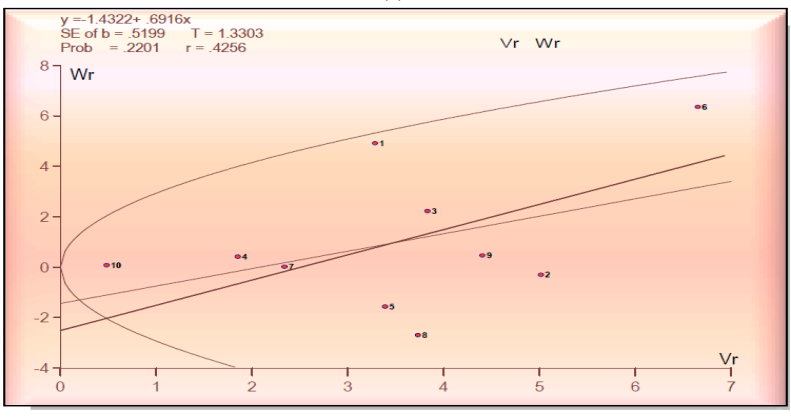

(h)

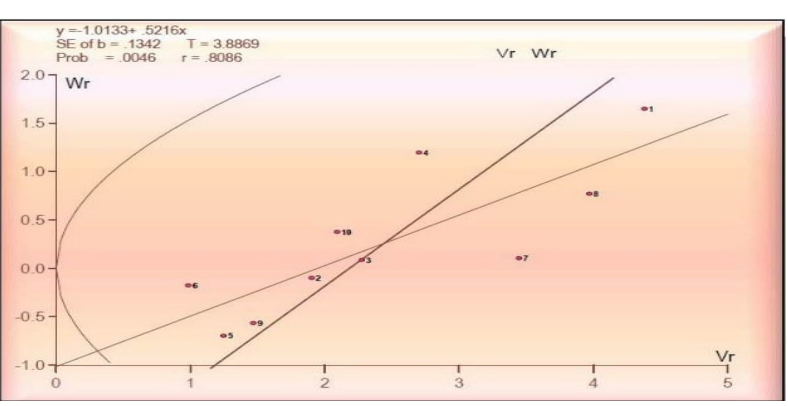

(i)

Fig. 1.Vr-Wr graph for various yield and quality traits in which (a) days to ear emergence, (b) days to 50\% flowering, (c) spike length, (d) peduncle length, (e) biological yield, (f) productive tillers, (g) harvest index, (h) flag leaf area, (i) grain yield, Vr (Y axis) and $W r$ (X axis), 1: $P B W$ 435, 2: HD 2967, 3: MP 3336, 4: MP 4010, 5: DBW 90, 6: HD 2824, 7: HD 3095, 8: RAJ 4246, 9: NW 5038 10: HD 2733. 
for developing future genotypes having higher yield. The parent RAJ 4246 contain maximum dominant genes for days to ear emergence and days to $50 \%$ flowering and parent HD 2824 contain maximum dominant genes for productive tillers, biological yield and grain yield therefore these varieties can be used for the development of short duration and high yielding genotypes in future breeding programme. In summary, the salient findings from the present investigation could be very useful while formulating breeding programme targeted to development of high yielding wheat genotypes and thereby ensure food and nutritional security for the country.

\section{Conclusion}

Based on the above findings, it may be concluded that both additive (fixable) and non-additive (non fixable) components of genetic variances were involved in the expression of majority of the traits from the present set of breeding material. Therefore, biparental mating and/ or diallel selective mating would be useful to exploit both additive and non additive type of gene action. Based on the results of regression analysis, it might be concluded that traits viz; days to ear emergence, days to $50 \%$ flowering, peduncle length, flag leaf area, productive tillers, harvest index, biological yield and grain yield that were largely governed by non-additive gene action, delayed selection to letter generations may be rewarding for these traits. The parent RAJ 4246 contained maximum dominant genes for days to ear emergence and days to 50\% flowering; HD 2733 for spike length and flag leaf area and HD 2824 for productive tillers, biological yield and grain yield used as a donors in multiple traits wheat breeding programme to develop high yielding wheat genotypes. The traits namely flag leaf area (91), days to ear emergence (75), grain yield (71), peduncle length (69), productive tillers (47), harvest index (42), spike length (36) and biological yield (30) that showed more than $30 \%$ narrow sense heritability can play greater role for additive genetic components therefore selection for these traits in early generation would be effective. Therefore, present findings could help in formulating future breeding programme to develop high yielding wheat genotypes for food security.

\section{REFFERNCES}

Anonymous (2016). Progress Report of all India Coordinated Wheat and Barley Improvement Project, 1-5 pp G. P. Singh (Ed). Indian Institute of Wheat and Barley Research, Karnal.
Dere, S. and Yildirim, M.B. (2006). Inheritance of plant height, tiller number per plant, spike height and 1000kernel weight in a $8 \times 8$ diallel cross population of bread wheat. Cereal Research Communications, 34 (2\&3): 965-72.

Dayal, L.S, Sastry, E.V.D. and Jakhar, M.L.(2003). Genetic architecture of yield and its component traits in bread wheat (Triticumaestivum L.) grown under saline and normal environments. Indian Journal of Genetics and Plant Breeding, 63 (4): 335-6.

Hayman, B.I. (1954). The theory and analysis of diallelcrosses.Genetics, 39 (6):789-809.

Kumar, D., Kerkhi, S.A., Singh, G. and Singh, J.B. (2015). Estimates of genetic parameters for grain yield, agromorphological traits and quality attributes in bread wheat (Triticum aestivum). Indian Journal of Agricultural Sciences, 85 (5): 622-7.

Kumar Pradeep, Singh Gyanendra, Singh Devi and Sirohi Anil. (2016a). Genetic architecture of various agromorphological and some quality traits in bread wheat (Triticum aestivum L). Indian Journal of Agricultural Science, 86 (12): 1530-35.

Kumar Pradeep, Nagar, S.S., Singh, Y.P., Abhishek, D. and Kumar, R. (2016b). Study of gene action for yield components and gluten content in bread wheat (Triticum aestivum L.).Ecology, Environment \& Conservation, 22 (2): 703-709.

Kumar, D., Kerkhi, S.A., Singh Y.P., and Bind, H. (2016c). Regression analysis for yield components and quality traits in wheat. Journal of Wheat Research, 8(1): 25-29.

Mather, K. and Jinks, J.L. (1982). Biometrical Genetics: The Study of Continuous Variation. Chapman and Hall Inc., London.

Panse, V.G. and Sukhatme, P.V. (1967).Statistical Methods of Agricultural Workers. $2^{\text {nd }}$ Endorsement, ICAR Publication, New Delhi, India, pp: 381.

Singh Gyanendra, Tyagi, B.S., Singh, G.P., Chatrath,R., Singh, D.P. and Jag Shoran. (2008). Genetic analysis and association of spot blotch resistance caused by $\mathrm{Bi}$ polaris sorokiniana with morphological and yield attributes in bread wheat (Triticum aestivum L.). Indian Journal of Agricultural Sciences, 78 (11) : 957-961.

Singh, H., Sharma, S.N., Saini, R.S. and Singhania, D.L. (2003).The inheritance of production traits in bread wheat by diallel analysis.SABRAO Journal of Breeding and Genetics, 35 (1): 1-9.

Singh, M.K., Sharma, P.K., Tyagi, B.S. and Singh, G. (2014).Combining ability analysis for yield and protein content in bread wheat (TriticumaestivumL.).Indian Journal of Agricultural Sciences, 84 (3): 328-36.

Singh, V., Krishna, R., Singh, L. and Singh, S.(2012). Analysis of yield traits regarding variability, selection parameters and their implication for genetic improvement in wheat (Triticum aestivum L.). SABRAO Journal of Breeding and Genetics 44(2): 370-381 